\title{
Optimization Of Financial Inclusion Through Sharia Banking Redistributive Instruments
}

\section{Novia Nengsih 1}

${ }^{1}$ Institut Agama Islam Negeri Batusangkar, Indonesia. novianengsih@iainbatusangkar.ac.id

\begin{abstract}
Purpose - This study aims to analyze the optimization of financial inclusion using Islamic banking redistributive instruments.

Method - This study aims to analyze the optimization of financial inclusion using Islamic banking redistributive instruments.

Result - The main finding of this research is that Islamic banking can optimize financial inclusion using the redistributive instruments of syari'ah banking namely zakat, Qardul Hasan, and other merit funds. This is indicated by the growth of zakat funds, benevolence funds, and increased qardul hasan financing.

Implication - This research can be used as a reference to determine the optimization of financial inclusion by Islamic banking using the redistributive instrument of zakat, qardhul hasan, and other merit funds.

Originality - This study analyzes the optimization of financial inclusion through the redistributive instrument of Islamic banking with qualitative and quantitative approaches.
\end{abstract}

Keywords: financial inclusion; redistributive instruments; sharia banking; zakat; qardhul hasan. 
Novia Nengsih

\section{Introduction}

The recent economic conditions in Indonesia are quite alarming. Based on a survey by the Swiss financial institution, Credit Suisse Global Wealt Databoks, Indonesia is the fourth most imbalanced country in the world after Russia, India and Thailand. The richest one percent in Indonesia controls 49.3 percent of the national wealth (Report, 2017). Data from the Central Statistics Agency (BPS) in March 2020 explained that the level of expenditure inequality of the Indonesian population as measured by the Gini Ratio was 0.381 . This figure is an increase of 0.001 points when compared to the Gini Ratio of September 2019 which was 0.380 and decreased by 0.001 points compared to the Gini Ratio of March 2019 which was 0.382 . The Gini Ratio in urban areas in March 2020 was recorded at 0.393 , an increase compared to the Gini Ratio in September 2019 which was 0.391 and the Gini Ratio in March 2019 which was 0.392. The Gini Ratio in rural areas in March 2020 was recorded at 0.317, an increase compared to the Gini Ratio in September 2019 which was 0.315 and unchanged from the Gini Ratio in March 2019 which was 0.317. Based on the measure of inequality by the World Bank, the distribution of expenditure in the bottom 40 percent is 17.73 percent. This means that population expenditure in March 2020 is in the low level of inequality category. If broken down by region, in urban areas the figure is 16.93 percent, which means it belongs to the moderate inequality category (BPS, 2020). Meanwhile, for rural areas, the figure was recorded at 20.62 percent, which means it belongs to the low inequality category.

The condition of the Indonesian economy is increasingly worrying about the condition of Indonesia's financial inclusion. The economic inequality that was hoped to be resolved with financial inclusion is still far from expectations. Based on data from the World Bank, the Global Financial Inclusion Index states that Indonesia's Financial Inclusion Index is only 19.6 percent (Bold, 2011). This is still far below other countries such as Malaysia 66.7 percent, Philippines 26.5 percent, Thailand 77.7 percent, Vietnam 21.4 percent, India 35.2 percent, China 63.8 percent, Russia 48.2 percent, and Brazil 55.9 percent. 
Optimization Of Financial Inclusion Through ...

The data above shows that Indonesia is a country with a fairly high level of financial exclusion. This is also evident from the results of several surveys and research conducted by several national and international institutions. The results of a survey by the Demographic Institute FEUI in 2012, only 35.51\% of Indonesia's adult population has an account at a formal financial institution. This survey is in line with the results of the Bank Indonesia household survey in 2011 which showed that only $48 \%$ of Indonesia's population has savings at banks and non-bank financial institutions and non-financial institutions (nonformal). Meanwhile, the World Bank survey in 2011 stated that only 19.6\% of adults in Indonesia have accounts at formal financial institutions and this is still far from neighboring countries such as Malaysia and Thailand (Suangkupon, Ismail, Sucipto, \& Purwengtyas, 2014).

The World Bank survey (2010) shows that only 49 percent of Indonesian households have access to formal financial institutions. Bank Indonesia found a similar case in the Household Balance Sheet Survey (2011), which showed that the percentage of households saving at formal financial institutions and non-financial institutions was 48 percent. Thus, people who do not have any savings at all in banks and non-bank financial institutions are still relatively very high, namely $52 \%$. The two surveys mutually reinforce and support that Indonesian people's financial access to formal and non-formal financial institutions is still relatively low, due to this lack of financial literacy (Nugroho \& Purwanti, 2018) so that Indonesians who have limited access to the financial service system still need to be improved (Suangkupon et al., 2014).

In the face of a sluggish Indonesian economy, banking has become the driving force for the Indonesian economy through financial inclusion and the use of bank credit (Fitriana, Rustiadi, Fauzi, \& Anggraeni, 2019), considering that Indonesian banks have a share of financial activities of up to 80 percent. The existence and growth of sharia banking cannot be underestimated in building the national economy. Although until the end of 2016 the share of Islamic banking was still 5.17 percent, the growth was quite significant. In 2020 the market share of Islamic banking increased to 6.18 percent. The portion of the Islamic banking market share consists of Islamic commercial 
Novia Nengsih

banks contributing 65.33 percent, Islamic business units 32.17 percent, and Islamic public finance banks 2.5 percent. The growth of Islamic banking is also inseparable from the demographic bonus of Indonesia, which is predominantly Muslim. Islamic regulations make Islamic banking increasingly rapid. Islamic regulations such as zakat, infaq, alms, and other benevolent funds have a major contribution in developing Indonesia's socio-economy because these instruments already have separate posts in their distribution. Because of this, the authors are interested in researching the optimization of financial inclusion using Islamic banking redistributive instruments.

\section{Methods}

This research is a field research (field research) with quantitative and qualitative approaches (mixed method). Qualitative research is research that intends to understand the phenomena experienced by research subjects by means of descriptions in the form of words and language, in a special natural context and by utilizing various natural methods (Maleong, 2007). Qualitative research is methods for exploring and understanding the meaning that some individuals or groups of people perceive as derived from social or humanitarian problems (Creswell, 2012).

The author uses primary data and secondary data. Hendri Tanjung and Abrista Devi (2013) say that data that is ready / published by related agencies and can be directly used by researchers is called secondary data. Data that is not yet available and to obtain this data the researcher must use several research instruments such as questionnaires, interviews, observations, and so on, hence it is called primary data.

Primary data that the author means is data from interviews (interview). According to Lofland and Lofland (2013), the main data sources in qualitative research are words and actions, the rest is additional data in the form of documents and others. Qualitative primary data is generally in the form of variations in perceptions from respondents or customers. Direct interviews were conducted with Islamic banking. Secondary sources are in the form of Islamic Commercial Bank financial reports for the last six years, namely 2010- 
2014, sources from books, journals, articles, and various other sources related to the author's research. Secondary data is used to strengthen primary data.

Qualitative data analysis used the analysis technique developed by Straruss and Corbin (2007) with three major steps, namely (1) Open Coding, (2) Axial Coding, (3) Selective Coding. Open coding is a procedure of breaking down (detailing the completeness of the data), examining (checking), comparing (comparing), conceptualizing (explaining local concepts), categorizing (categorizing data). Meanwhile, at the axial coding stage there is a grounded theory model, namely the causal conditions? phenomenon ? context ? supporting and inhibiting conditions ? interaction strategy and action ?the consequences. The last stage is selective coding and producing conclusions which are then appointed as general design.

Quantitative analysis using comparative analysis between financial statements. According to Kasmir (2014), a comparative analysis between financial reports is an analysis by comparing financial reports in several periods, at least two or more periods. From this analysis, it will be known the changes that have occurred. Changes that occur can be in the form of an increase or decrease in each component of the analysis. From these changes, it can be seen that each progress or failure in achieving the targets that have been previously set.

\section{Results and Discussion}

Bank is one of the financial institutions that has an important role as financial intermediaries in the economy of a country (Marimin \& Romdhoni, 2017). Islamic banks are banks that carry out their business activities based on sharia principles. Indonesia started it Islamic banking industry in 1992 (Abdillah, Rabi, \& Firli, 2020). The development of the Islamic banking industry in Indonesia encouraging rate of growth (Nihayah \& Rifqi, 2020). Islamic financial institutions carry out their business activities based on the Al - Quran and Al - Hadith (Rifa'i, 2017). All Islamic financial activities are usually regulated by Islamic Banks (Antara, Musa, \& Hassan, 2016). In Islam, all activities carried out by a Muslim must be in accordance with Islamic law, 
Novia Nengsih

including in economic activities (Suhirman, 2020). Islam is a universal religion to regulate all aspects of life (Ilahi \& Afendi, 2019). Islamic bank is not only a different type from conventional banks but its existence as a revolution.

Inclusion can be defined as involvement, equitable distribution, and participation Melinda (Lestari, 2019). Financial inclusion is the process of providing formal financial access to poor people, that is, people who have not had access to formal financial institutions. Banking has an important role in providing access to unbankable people (Nengsih, 2015). With regard to inclusive growth (Sanjaya, 2016), the urgency of financial inclusion because financial inclusion can provide a multiplier effect for the economy by providing access to finance for the community so that they have the capital to do business (for MSME players) (Adriani \& Wiksuana, 2018) and in the end can improve their economy. 7 Financial inclusion aims so that no more obstacles occur so that it can be reached at a low cost in order to improve the welfare of the community.

Rajalaxmi Kamath wrote in his article entitled financial inclusion vis-à-vis social banking that financial inclusion is a process to ensure timely and adequate credit access and provide financial services to low-income groups (Kamath, 2007). Financial inclusion is also defined as a process to ensure access to financial products and services needed by all levels of society in general and low income groups in particular at affordable costs in a fair and transparent manner.

According to the CRC (Committee on Financial Inclusion under the Chairmanship of C Rajaratman) defines financial inclusion as a process of access to timely and adequate financial and credit services needed by vulnerable groups such as the weak and low-income groups at affordable costs. The World Bank and the European Commission 2008, also define financial inclusion as a comprehensive activity that aims to remove all forms of barriers, both in the form of prices and non-prices, to public access in using or utilizing financial services (Dasgupta, 2009). Financial inclusion can also be defined as the provision of banking services at affordable costs for low-income groups. This definition is very appropriate when giving credit to people in 
need. Credit is a very important component, but financial inclusion also includes various other financial services such as savings, insurance, payments and money transfer facilities by the formal financial system for people who tend to be excluded (Dev, 2009).

Financial inclusion is a national strategy to encourage economic growth through income distribution (Bahri, 2018). BI and OJK have launched a national strategy for financial inclusion (Kusuma, 2020). Financial inclusion aims to encourage unbankable people to have access to the formal financial system, so that they have the opportunity to access financial services ranging from savings, payments, financing, insurance, and various other financial services (Hannig \& Jansen, 2011). Another goal of financial inclusion is for all levels of society, especially the middle to lower class (in the bottom of the pyramid) (Laili \& Kusumaningtias, 2020) can have easy access to the use of financial services so as to encourage quality economic growth while simultaneously overcoming poverty (Irmawati, Damelia, \& Puspita, 2013). The ease of public access to the banking system will increase the country's economic growth. Financial inclusion also aims to reduce social disparities, save the poor from debt bondage to moneylenders due to the lack of access to financial institutions in their surrounding areas, and improve the welfare of the poor by increasing the ability of individuals to manage their finances. In this regard, Bank Indonesia issued 23 policy points covering five aspects, namely policies to strengthen monetary stability, policies to promote the role of banking intermediation, policies to increase banking resilience, strengthen macro prudential policies, and strengthen the supervisory function (Rini, 2013).

Financing is one of the functions of the Bank (Kurnia Aufa, Cita Sary Dja'kum, 2019). Islamic banking as an Islamic financial institution has advantages over other financial institutions. Islamic banking has redistributive instruments so that there are social funds that can be used to develop partnership programs and make social contributions to society. Among the redistributive instruments are: 1 . Optimizing Zakat as a redistributive instrument for Islamic banking. Zakat is the most effective and essential 
Novia Nengsih

instrument that is not found in the system of capitalism or socialism (Rahmawati, 2014). Iskandar Zulkarnain explained that Islam views poverty as a result of an unbalanced social system, a lack of social solidarity, and the development of crime in society and individual culture itself. These four elements must be corrected if we want to fight poverty, with the main elements in the policy economy (politics) being the main responsibility of the rulers of this country, meaning that overcoming poverty must be preceded by arranging the correct system (Islamic system), increasing social solidarity accompanied by by improving the quality of human resources. Zakat is considered a potential source of funds that can be used to help alleviate the suffering of the weak (Paramita \& Zulkarnain, 2018).

Muhammad Ismail Yusanto is of the view that poverty is also born from an individualistic social setting, where the rich with their egos are indifferent to the circumstances around them, including to realize that very many poor people need a helping hand. He is busy with himself and indifferent to others. Whereas in every penny there are actually the rights of the poor that play a direct or indirect role in the success of the rich. Poverty also occurs as a result of unfair distribution as an effect of the capitalist economy (Yusanto, 2001).

Indonesia as a country with the largest Muslim population (Rosyadah, Arifin, Muhtadi, \& Safik, 2020). The potential for zakat in Indonesia reaches Rp. 217 trillion. Overcoming poverty must be preceded by realizing an economic order that allows the birth of a fair distribution system, encouraging the birth of care for the poor (aghniya) for the poor, the dhuafa and the mustadhafin. One form of al-aghniya's concern is through the willingness to pay zakat and alms. In an economic context, these two things constitute a form of wealth distribution among humans, namely distribution that occurs through economic transactions (Yusanto, 2001).

Zakat is part of Islamic law which is one of the five pillars of Islam and the Islamic law according to as-Shatibi, is stipulated in the framework of realizing the benefit of mankind in the world and the hereafter (Habib, 2016; Shatibi, n.d.). Zakat as a maliyah worship which has dimensions of equal distribution of the gifts of Allah SWT as a socio-economic function as a manifestation of social 
solidarity, a statement of humanity and justice, proving Islamic brotherhood, binders the unity of the people, as a mental binder between the rich and the poor, a means of building closeness between the strong and the weak, creating a prosperous, harmonious, peaceful, and harmonious society that can ultimately create peace and justice.

Redistributive instruments such as zakat, infaq and alms are one of the ways to reduce poverty. The potential of zakat can support the realization of an Islamic social system that stands on the principles of: ummatan wahidatan (one people), musawwamah (equality of degrees and obligations), ukhuwah islamiyah (Islamic brotherhood) and takaful ijtima (collective responsibility). Zakat is an important element in creating a balance in the distribution of assets (social distribution) and individual responsibility in society (Lili Bariadi, 2005).

As a religious obligation, zakat is ordered by using fi'il amar. Zakat is mentioned in the Koran 82 times. Zakat is one of the pillars of Islam and is one of the pillars of Islam and is one of the main elements of the upholding of Islamic law. Therefore, zakat is fardlu on every Muslim who has met certain conditions. The commandment of zakat is repeated 82 times in the Koran. Among them in the letter al-Baqarah verse 110 Meaning: "And establish prayers and pay zakat. And whatever goodness you work for yourself, of course you will get a reward with Allah. Surely Allah sees everything you do. (QS. Al-Baqarah (2) : 110). The recipient of zakat has also been allocated by Allah to the economically weak groups, as Allah said in surah at-Taubah verse 60: This means: "In fact, zakat-zakat is only for the needy, the poor, the administrators of zakat, the converts who are persuaded by their hearts, to (free) slaves, people who owe for the way of Allah and for those who are on the way, as a decree which Allah obliges, and Allah is All-Knowing, Most Wise. (Surah At-Taubah (9): 60). In surah at-Taubah verse 60 Allah describes the recipients of zakat (mustahiq zakat), namely indigent, poor, 'amil, converts, to liberate slaves, people in debt, and people who are fighting in the way of Allah. Only people who have been determined by Allah are entitled to receive zakat.

Zakat has a social dimension. This is the virtue of zakat when compared to other teachings showing that only zakat is considered to be laden with social 
Novia Nengsih

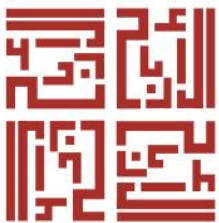

AL-ARBAH | 230

values. Therefore, it is impossible to ignore zakat in the chain of increasing the welfare of the people. In a contemporary economic perspective, zakat is considered to have a distributional impact to reduce the income gap between the rich and the poor. Zakat can also stimulate the economic demands of the poor by increasing output and employment. So, if zakat is paid according to the Shari'a, poverty can be eliminated by reducing poor Muslims (Rauf, 2009).

In terms of empowering and building the welfare of the people in the economic sector, there are at least 3 aspects related to the implementation of the zakat obligation. First, moral and psychological aspects. In this aspect, it is hoped that zakat can eradicate greed and greed which tend to love wealth. Second, the social aspect, in this case zakat acts as a unique tool given by Islam to eradicate poverty levels in society and at the same time make them aware of the social responsibility imposed by religion. And third, the economic aspect, here zakat is functioned to prevent the accumulation of assets and narrow the economic gap in society (Risya, 2009).

Ascarya explained that the application of the zakat system will have various implications in various aspects of life, including (Ascarya, 2007): Meet the needs of people who are in need; Reducing the economic gap; Reducing the number of social problems, crime, prostitution, homeless people, beggars, and others; Maintain the purchasing power of the community in order to maintain the business sector. In other words, zakat keeps people's consumption at a minimum level so that the economy can continue to run; Encouraging people to invest, not piling up assets (idle).

Didin Hafidhuddin explained that there are six wisdoms and benefits of zakat. First, as a manifestation of faith in Allah SWT, be grateful for His blessings and cultivate noble morals. Second, zakat functions to help, assist and foster mustahiq towards a better life. Third, as a pillar of common charity (jama'i) between rich people. Fourth, as a source of funds for the construction of facilities and infrastructure that must be owned by Muslims. Fifth, to promote business ethics. Sixth, in terms of developing the welfare of the people, zakat is an instrument of income distribution. With zakat that is well managed, it is 
Optimization Of Financial Inclusion Through ...

possible to build economic growth as well as equal income distribution, economic with equity (Hafidhuddin, 2002; Qardlawi, 1991; Saefuddin, 1996).

Monzer Kahf states that zakat and the Islamic inheritance system tends towards an egalitarian distribution of property and that as a benefit of zakat, property will always be circulated (Kahf, 1955). Mustaq Ahmad states that zakat is the main source of state treasury and at the same time is the pillar of economic life proclaimed by al-Qura $>\mathrm{n}$. Zakat will prevent the accumulation of wealth in one hand and at the same time encourage people to invest and promote distribution. Zakat is a comprehensive institution for the distribution of assets (Ahmad, 2001; Hafidhuddin, 2002).

With the zakat mechanism, economic activity in the worst condition will certainly be able to run at least at the minimum level to meet primary needs. Therefore, the zakat instrument can be used as the last shield for the economy so that it does not fall into a crisis where consumption capacity is stagnant (underconsumption). Zakat allows the economy to continue running at a minimum level, because the minimum consumption requirement is guaranteed by the zakat fund. In summary, the application of the zakat system will have a positive impact on the real sector in several ways, including (Ascarya, 2007): Zakat is a standard mechanism that ensures the distribution of income and wealth so that there is no tendency for the accumulation of factors of production in a group of people that has the potential to hinder economic growth; 2. Zakat is a mechanism of economic turnover (velocity) itself that maintains the level of demand in the economy. In other words, the market is always available for producers to offer offers. That way, the real sector is always maintained at a minimum level, the economy can continue because the interaction of demand and supply is always there; 3. Zakat accommodates citizens who do not have access to the market because they do not have purchasing power or capital to become active actors in the economy so that the volume of economic activity is relatively larger when compared to conventional economic activities. 
Novia Nengsih

Table 1. Amount of zakat funds for Sharia Bank $X$ and Sharia Bank $Y$ in Million rupiah

\begin{tabular}{llllllllll}
\hline Bank & 2015 & 2016 & $\Delta \%$ & 2017 & $\Delta \%$ & 2018 & $\Delta$ & 2019 & $\begin{array}{c}\Delta \\
\%\end{array}$ \\
\hline $\mathbf{X}$ & 22.85 & 24.321 & 6,44 & 26.029 & 7,02 & 35.326 & 35,71 & 61.515 & 74,13 \\
& & & & & & & & &
\end{tabular}

Information

$\mathrm{X}$ is Sharia Bank X (One of the BUS in Indonesia)

Y is a Sharia Bank Y (One of the BUS in Indonesia)

$\triangle$ Annual Growth

With the increase in aggregate demand and then followed by the increase in aggregate supply from time to time, zakat in the economy will increase the welfare of society. This multiplier effect will be created if zakat is implemented optimally for the community. The zakat function optimization is shown in the table 1.

Table of zakat funds under sharia is always used for social activities. Sharia Bank X zakat funds have positive growth during 2015 - 2019. Sharia Bank X zakat funds come from bank zakat, zakat from customers and the public, and zakat from bank employees. All of these zakat funds are channeled through the Sharia Bank X National Amil Zakat Institution (LAZNAS Bank Syariah X). Laznas Bank Syariah X is an official institution that is recognized as a recipient of zakat or mandatory religious donations which can be deducted from gross income.

Laznas Bank Syariah X distributes zakat funds through community partners, educating people, and sympathy for the people. The community partner program is in the form of community micro business assistance in the form of working capital and business training for Islamic microfinance institutions (LKMS). The community education program is a program in the field of education by providing scholarships from elementary to tertiary level, forming a house of achievement, and khadijah Islamic School. Meanwhile, the sympathy program is an activity carried out continuously to anticipate 
Optimization Of Financial Inclusion Through ...

emergency conditions and actively participate in reducing the impact of social and natural disasters. This program is channeled through disaster response activities, healthy homes, and healthy clinics .

Sharia Bank Y zakat funds experienced significant growth from 20152019. Sharia Bank Y zakat funds come from internal and external banks. Within the bank, this zakat comes from zakat from the bank and zakat from bank employees. It was recorded that in 2015, Sharia Bank Y distributed zakat funds of 3.2 billion. The zakat funds are channeled through Baznas. Bank Syariah Y acknowledges that Baznas is a professional institution and distributes zakat according to the target.

Similar to zakat, infaq and alms also have extraordinary socio-economic elements. Infaq is something that is given by someone to cover the needs of others, in the form of food, drink, and so on; in other words donating or giving sustenance (gift) or giving something to others based on sincerity because of Allah SWT alone. Infaq issues assets which include zakat and non zakat. Infaq is obligatory and sunnah. Mandatory infaq, for example, kafarat, nadzar, zakat, and others. Infaq sunnah is like Infaq to victims of natural disasters. So Infaq means spending some of the assets for the sake of what is ordered by Islamic teachings (Dahlan, 2000; Risya, 2009b).

Almsgiving is a gift from a Muslim voluntarily without being limited by a certain time and amount, a gift made by someone as a virtue that hopes for the pleasure of Allah and only reward. Almsgiving is broader than zakat and infaq. Alms can be infaq, zakat, and non-material kindness. Almsgiving is an expression of honesty. Almsgiving is not only about money but also nonmaterial (Dahlan, 2000; Risya, 2009b).

Infaq and alms both donate something to others, but there is a difference in the time spent. Infaq the time it is spent is when it gets sustenance from Allah SWT and without determining the level and amount spent. Meanwhile, there is no stipulation of time for alms, nor is there any stipulation regarding the amount of its allocation (Abdad, 2003). 
Novia Nengsih

Infaq and alms are different from zakat which is clear to whom to give. Infaq and alms are the practices of circumcision that are highly recommended by Allah, but the distribution of both is left to the owner. There are indeed verses and hadith findings which state that infaq and alms are prioritized to be given to family and close relatives. However, priorities for immediate family should not be understood that infaq and alms are not allowed to be given to non-relatives.

Islam priorituzes charity over ideas (Toyyibi, 2019). Giving alms or donations to the poor without expecting anything in return. These funds are allocated for the needs of the poor which are basic needs (Basic Needs). The contract used in this case is a grant contract. At this stage, the internalization of educational values that can change the character of the poor has begun (Antonio \& Nugraha, 2013).

Although there are differences of opinion among the jurists about who is entitled to receive infaq, the most important thing is that infaq and almsgiving as redistributive instruments for Islamic economics and Islamic banking in particular, will have a very broad socio-economic effect on society. The existence of Islamic banking redistributive instruments, such as zakat, infaq, alms, can be used as capital as well as a model for economic system development and accelerate the implementation of financial inclusion through Islamic banking (Suma, 2015).

Loan of Virtue Without Interest (Qardh al-Hasan). Qardh is a benevolent loan without compensation, usually for the purchase of fungible goods. Qard includes a mutual assistance agreement - help and not a commercial transaction (Asy-Syarbasyi, 1987). Akad means bond (Ma'luf, 1986). The contract also has the meaning of bondage, binding together (Wehr, 1980). Akad or in English is contract (Usman \& Rasiam, 2019). The object of a qardh loan is usually money or other means of exchange, which is a pure interest-free loan transaction when the borrower gets cash from the owner of the fund (in this case the bank) and is only obliged to return the principal of the debt at a certain time in the future. A qardh al-hasan loan is a virtue loan that is not commercial in nature, but is social in nature (Ascarya, 2007; Veithzal \& Arifin, 
2010). Giving preliminary loans by means of qardh is more concerned with Allah SWT than giving alms (Suryadi \& Putri, 2018).

Syafii Anthonio explained that the qardh contract is usually applied in banking applications as follows (Anthonio, 2001): 1. As a complementary product to customers who have proven loyalty and bona fide, who need an immediate bailout for a relatively short period. The customer will return the loan amount as soon as possible; 2. As a facility for customers who need fast funds, they cannot withdraw their funds because, for example, they are stored in the form of deposits; 3 . As a product to contribute to very small businesses or help the social sector. In order to fulfill this scheme, a special product called al qardhh al hasan is known. The benefits of qardh are many, including (Anthonio, 2001): 1. Allows customers who are in urgent trouble to get shortterm bailouts; 2. Qardh al-Hasan is also one of the distinguishing characteristics between Islamic banks and conventional banks, which contains a social mission in addition to a commercial mission; 3. The existence of this social community mission will improve a good image and increase public loyalty to Islamic banks. Ahmad Rodhoni more applicatively explained that qardh in banking is usually in four ways, namely (Rodhoni \& Hamid, 2008): 1. As a hajj bailout loan, where prospective hajj customers are given a bailout loan to fulfill the requirements for depositing costs for the pilgrimage trip. The customer will pay it before the Hajj departure; 2. As a cash loan (cash advanced) from Islamic credit card products, where customers are given the power to withdraw cash through a bank (ATM). The customer will return it within the specified time; 3 . As a loan to small entrepreneurs, where according to bank calculations it will be burdensome for the entrepreneur if it is provided with financing by means of a buying and selling scheme, ijarah or profit sharing; 4. As a loan to bank managers, where the bank provides this facility to ensure the fulfillment of bank management needs. the bank management will return it in installments by deducting his salary.

Soft Loans (Soft Loan) is a type of financing with a qardh contract. This loan is better than giving from alms because when someone makes a loan, it means they are in need of funds. In addition, if the loan provision is managed properly, 
Novia Nengsih

there will be a building commitment to repay the loan at the agreed time. In this context, the role of social intermediation related to educational programs is carried out. The community has gained an understanding of self-potential (self-reliance), entrepreneurship, discipline in paying debt installments and others that lead to self-development and family economics. The contract carried out in this second stage is the qardh al-Hasan contract, where the community is required to repay the loan according to the initial loan amount (Antonio \& Nugraha, 2013).

The risk of a benevolent qardh al-Hasan loan is quite high because this loan is unsecured financing, but the benefits are enormous, among others (Anthonio, 2001): 1. Qardh al-Hasan allows customers who are in urgent trouble to get short-term bailouts; 2. Qardh al-Hasan is one of the distinguishing features between Islamic banks and conventional banks, which contains a social mission in addition to a commercial mission; 3 . The existence of this social community mission will improve the good image and increase public loyalty to Islamic banks.

On a micro level, qardh will not be of direct benefit to the lender. On the macro side, however, qardh will provide indirect benefits to the economy as a whole. This is because the provision of qardh provides a velocity of money (the acceleration of the circulation of money) will increase rapidly, which means that new funds are added to the economy, so that national income will increase. Likewise, spending alms will also provide benefits that are more or less the same as giving qardh (Veithzal \& Arifin, 2010).

Table 2. Amount of Funds for Virtue in 2015-2019 Million rupiah

\begin{tabular}{lccccccccc}
\hline Bank & 2015 & 2016 & $\triangle$ & 2017 & $\triangle \%$ & 2018 & $\triangle$ & 2019 & $\nwarrow$ \\
\hline $\mathbf{X}$ & 22.826 & 23.738 & 3,99 & 24.859 & 4,72 & 24.973 & 0,45 & 26.432 & 5,84 \\
$\mathbf{Y}$ & 246 & 553 & 124,79 & 1.356 & 145,2 & 2.683 & 97,86 & 2.185 & $-18,56$ \\
\hline
\end{tabular}


Optimization Of Financial Inclusion Through ...

Table 2 is the benevolence fund of Islamic Bank X and Islamic Bank Y. Overall the data shows that the benevolence fund has grown from year to year. The distribution of these benevolent funds varies. Bank Syariah X distributes benevolence funds through Laznas Bank Syariah X and Bank Syariah Y channels virtue funds through donations.

Sources of funds for the goodness of Bank Syariah X are from fines, donations / grants, receipt of non-halal funds, and other social funds such as infaq and alms. Islamic Bank Y's benevolence funds come from infaq and alms, fines, and non-halal income.

The benevolence fund is one of the social instruments that can have a direct effect on the grass root community, but has not been managed optimally by Islamic banking. The not optimal management of benevolence funds can be seen from the incomplete recording of benevolence funds, there are even some Islamic banks that have not recorded their benevolence funds. The non-halal fund component should not be included in the benevolent fund component, because benevolent funds are soft loan funds without social benefits.

Sharia banking is expected to optimize the management of virtue funds in the context of implementing Islamic banking in accordance with the main objective of Islamic economics, namely falah. Sharia banking is also expected to carry out administrative improvements related to virtue funds. Optimizing the use of benevolent funds that are right on target will accelerate the implementation of financial inclusion, because these benevolence funds directly touch the unbankable people without having to go through BPRS or BMT intermediaries.

Set aside a portion of the profit for social activities. The continuity of the Bank's business cannot be separated from the participation of the public in welcoming the various Islamic banking products and services offered by the Bank. Public participation and support for the achievement of the Bank's performance requires banks to provide reciprocal benefits to the community as a form of social responsibility.Islamic banking participates in various social 
Novia Nengsih

activities with the community. CSR (Corporate Social Responsibility) funds are truly prepared for the welfare of the community. Islamic banks also take part in the scientific development of Islamic economics through the educational scholarships they provide. Through this CSR, Islamic banks can also help the poor, so that Islamic banks as the locomotive for the implementation of financial inclusion in Indonesia are not impossible.

Corporate Social Responsibility(CSR) refers to all relationships that occur between the company and all stakeholders, including customers, employees, communities, owners, governments, suppliers and even competitors. CSR activities are strived to help overcome or reduce problems that occur in society, seek to change people's behavior, and strive to achieve community welfare.

Islamic Bank X as one of the Sharia Commercial Banks (BUS) contributes to the social aspects of society. Community empowerment activities take place simultaneously with the Bank's operational activities in achieving the Millennium Development Goals (MDG's) targets through community partner programs and micro and small business financing (Sustainability Report Bank syariah X, 2019).

The implementation of corporate social responsibility (CSR) in support of improving the quality of life of the community is carried out in the form of the Didik Umat Program and the Sympathy Umat Program in collaboration with LAZNAS Bank Syariah X. The Dididk Umat Program is carried out through the provision of educational assistance and scholarship assistance. Meanwhile, the implementation of the Sympathy Umat Program through the provision of public facilities and infrastructure assistance and assistance to repair clean water and sanitation channels reached Rp3.87 billion. Islamic Bank X also provided house renovation assistance in Cibinong, Bogor, Ponorogo, and Klaten with a total of IDR 118.57 million (Sustainability Report Bank Syariah Y, 2019).

Bank Syariah X realizes community development programs through the Umat Partners Program in collaboration with LAZNAS. The Mitra Umat 
Optimization Of Financial Inclusion Through ...

Program is a community development program around the operational area of the Bank, with the ultimate goal of improving the welfare of the community and lifting the nation's economy. During 2015, Bank syariah X has implemented the Umat Partners Program in the context of empowering the community's economy with a total allocation of funds distributed as much as Rp9.14 billion, while the funds distributed in 2015 amounted to Rp.10.20 billion. The number of recipients of funds for the Umat Partners Program in 2016 was 3,123 people and 111 institutions (Sustainability Report Bank syariah X, 2019).

In 2015, Bank Syariah Y has distributed CSR assistance of Rp. 2.72 billion for CSR programs. The programs financed by Bank Syariah Y through its CSR program are educational assistance with a realization of $7 \%$ in 2014 , health assistance of $8 \%$, assistance for public facilities and the environment by $5 \%$, assistance, disasters and disasters 47\%, da'wah and assistance worship facilities 19\%, and economic empowerment 11\% (Annual Report Bank syariah Y, 2019). Optimizing CSR programs will accelerate the implementation of financial inclusion.

\section{Conclusion}

Islamic banking can optimize financial inclusion as a key priority and a means of reducing poverty by using the redistributive instruments of syari'ah banking, namely zakat, Qardul Hasan, and other benevolent funds. This is indicated by the growth of zakat funds, benevolence funds, and increased qardul hasan financing. Every year the zakat fund of Islamic banking increases by 30 percent on average, the benevolence fund grows by an average of 290 percent, and qardul hasan financing also increases following the increase in the benevolence fund. The demographic bonus of Indonesia, which is predominantly Muslim, also contributes positively to optimizing financial inclusion using redistibutive Islamic banking instruments. 
Novia Nengsih

\section{References}

Abdad, M. Z. (2003). Lembaga Perekonomian Umat di Dunia Islam. Bandung: Angkasa.

Abdillah, M. Y., Rabi, M. E., \& Firli, R. N. (2020). Tawarruq Application in Islamic Banking: A Comparative Study between Malaysia and Indonesia. Al-Arbah: Journal of Islamic Finance and Banking, 2(1), $17-32$. https://doi.org/http://dx.doi.org/10.21580/alarbah.v2i1.5540

Adriani, D., \& Wiksuana, I. G. B. (2018). INKLUSI KEUANGAN DALAM HUBUNGANNYA DENGAN PERTUMBUHAN UMKM DAN TINGKAT KESEJAHTERAAN MASYARAKAT DI PROVINSI BALI. E-Jurnal Manajemen Universitas Udayana, 7(12), 6420. https://doi.org/10.24843/ejmunud.2018.v07.i12.p02

Ahmad, M. (2001). Etika Bisnis Dalam Islam. Jakarta: Pustaka AlKautsar.

Annual Report Bank syariah Y. (2019).

Antara, P. M., Musa, R., \& Hassan, F. (2016). Bridging Islamic Financial Literacy and Halal Literacy: The Way Forward in Halal Ecosystem. Procedia Economics and Finance, 37, 196-202. https://doi.org/10.1016/s2212-5671(16)30113-7

Anthonio, S. (2001). Bank Syariah dari Teori ke Praktek. Jakarta: Gema Insani.

Antonio, S., \& Nugraha, H. F. (2013). Peran Intermediasi Sosial Perbankan Syariah bagi Masyarakat Miskin. TSAQAFAH, 9(1), 123. https://doi.org/10.21111/tsaqafah.v9i1.43

Ascarya. (2007). Akad \& Produk Bank Syaria. Jakarta: PT. Raja Grafindo Persada.

Asy-Syarbasyi, A. (1987). al-Mu'jam al-Iqtisad al-Islami. Beirut: Daramil Kutub.

Bahri, A. R. (2018). Model Inklusi Keuangan Terhadap Arah Pengembangan Nilai CSR Perbankan (Studi Kasus Program CSRBNI 46 di Usaha Batik Lasem). Retrieved January 22, 2021, from 
Optimization Of Financial Inclusion Through ...

Journal of Management website: https://jurnal.unpand.ac.id/index.php/MS/article/view/1112

Bold, C. (2011). Branchless Banking in Pakistan: A Laboratory for Innovation. Retrieved from Washington, DC: World Bank website: https://openknowledge.worldbank.org/handle/10986/9449

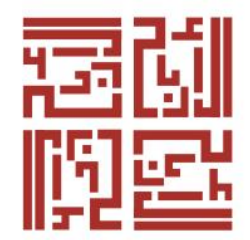

Creswell, J. W. (2012). Research Design Pendekatan Kuallitatif, Kuantitatif, dan Mixed. Yogyakarta: Pustaka Pelajar.

Dahlan, A. A. (2000). Ensiklopedia Hukum Islam (Jilid V). Jakarta: Ichtiar Baru Van Hoeve.

Dasgupta, R. (2009). Two Approaches to Financial Inclusion on JSTOR. Economic and Political Weekly , 44(26). Retrieved from https://www.jstor.org/stable/40279775?seq=1

Dev, S. M. (2009). Financial Inclusion: Issues and Challenges . Economic and Political Weekly, 44(41), 4310-4313. Retrieved from https://www.jstor.org/stable/4418799?seq=1

Fitriana, W., Rustiadi, E., Fauzi, A., \& Anggraeni, L. (2019). Penguatan Inklusi Keuangan pada Industri Kreatif Berskala Mikro Kecil di Sumatra Barat. Jurnal Ekonomi Dan Pembangunan Indonesia, 140153. https://doi.org/10.21002/jepi.v0i0.1112

Habib, A. A. (2016). THE PRINCIPLE OF ZAKAT, INFAQ, AND SHADAQAH ACCOUNTING BASED SFAS 109. Journal of Accounting and Business Education, 1(1), https://doi.org/10.26675/jabe.v1i1.6725

Hafidhuddin, D. (2002). Zakat dalam perekonomian Modern. Jakarta: Gema Insani Press.

Hannig, A., \& Jansen, S. (2011). Financial inclusion and financial stability: Current policy issues. In Financial Market Regulation and Reforms in Emerging Markets (pp. 284-318). https://doi.org/10.2139/ssrn.1729122

Ilahi, A. P., \& Afendi, A. (2019). Factors To Influence Employee Performance In Bank Tabungan Negara Sharia Semarang. Journal of Islamic Finance and Banking, 1(1), 1-18. https://doi.org/10.21580/al-arbah.2019.1.1.4108 
Novia Nengsih

Irmawati, S., Damelia, D., \& Puspita, D. W. (2013). MODEL INKLUSI KEUANGAN PADA UMKM BERBASIS PEDESAAN. JEJAK: Jurnal Ekonomi Dan Kebijakan, 6(2), 103-213. https://doi.org/10.15294/jejak.v6i2.3885

Kahf, M. (1955). Ekonomi Islam, Telaah Analitik Terhadap Fungsi Sistem Ekonomi Islam. Yogyakarta: Pustaka Pelajar.

Kamath, R. (2007). Financial Inclusion vis-a-vis Social Banking . Economic and Political Weekly, 42(15), 1334-1335. Retrieved from

https://www.epw.in/journal/2007/15/commentary/financialinclusion-vis-vis-social-banking.html

Kurnia Aufa, Cita Sary Dja'kum, E. (2019). Risks Of Sharia Commercial Bank In Indonesia: Analysis Of Internal And External Factors. ALARBAH: Journal of Islamic Finance and Banking, 1(1).

Kusuma, I. N. P. (2020). Pengaruh Literasi Keuangan terhadap Inklusi Keuangan melalui Financial Technology pada UMKM di Bandar Lampung. Jurnal Manajemen Bisnis Dan Kewirausahaan, 4(5), 247. https://doi.org/10.24912/jmbk.v4i5.9236

Laili, N. Y., \& Kusumaningtias, R. (2020). Efektivitas Inklusi Keuangan Syariah dalam Meningkatkan Pemberdayaan UMKM (Studi Pada BMT Dasa Tambakboyo). Jurnal Ilmiah Ekonomi Islam, 6(03), 436443. https://doi.org/10.29040/jiei.v6i3.1204

Lestari, N. M. (2019). Pengaruh Tingkat Literasi Mahasiswa Perbankan Syariah Terhadap Inklusi Keuangan Produk Perbankan Syariah dalam Transaksi E-commerce. Jurnal Ekonomi Islam, 10(2). Retrieved from https://journal.uhamka.ac.id/index.php/jei/article/view/3764

Lili Bariadi, E. a. (2005). Zakat \& Entrepreneurship. Jakarta: central for entrepreneurship development.

Ma'luf, L. (1986). Al-Munjid fi al-Lughah. Beirut: Dar al-Masyriq.

Maleong, L. J. (2007). Metodologi Penelitian Kualitatif. Bandung: PT. Remaja Rosdakarya.

Marimin, A., \& Romdhoni, A. H. (2017). PERKEMBANGAN BANK 
SYARIAH DI INDONESIA. Jurnal Ilmiah Ekonomi Islam, 1(02). https://doi.org/10.29040/jiei.v1i02.30

Nengsih, N. (2015). Peran Perbankan Syariah Dalam

Mengimplementasikan Keuangan Inklusif di Indonesia. ETIKONOMI, 14(2). https://doi.org/10.15408/etk.v14i2.2272

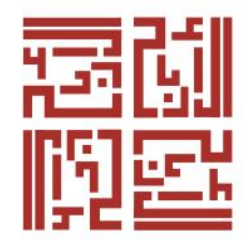

Nihayah, A. Z., \& Rifqi, L. H. (2020). Variables Determining For Impairment On Productive Assets In Islamic Banks In Indonesia. Journal of Islamic Finance and Banking, 2(1), 1-16. https://doi.org/http://dx.doi.org/10.21580/al-arbah.v2i1.5539

Nugroho, A., \& Purwanti, E. Y. (2018). DETERMINAN INKLUSI KEUANGAN DI INDONESIA (GLOBAL FINDEX 2014). JURNAL DINAMIKA EKONOMI PEMBANGUNAN, 1(1), 1. https://doi.org/10.14710/jdep.1.1.1-13

Paramita, M., \& Zulkarnain, M. I. (2018). The Role of Islamic Microfinance Institutions in Fulfilling the Capital Needs of Micro, Small and Medium Enterprises. Journal of Syarikah, 4(1). https://doi.org/10.30997/jsei.v4i1.1221

Qardlawi, Y. (1991). Fiqhuz Zaka>h. Beirut: Muassasah Risalah.

Rahmawati, A. (2014). Distribusi Dalam Ekonomi Islam: Upaya

Pemerataan Kesejahteraan Melalui Keadilan Distributif. Equilibrium, $1 . \quad$ Retrieved from https://journal.iainkudus.ac.id/index.php/equilibrium/article/vi ew/198

Rauf, F. (2009). Foreword on Zakat for Poverty Alleviation Written. Jakarta: PP LAZISNU.

Report, G. W. (2017). Research Institute; Thought leadership from Credit Suisse Research and the world's foremost experts.

Rifa'i, A. (2017). Peran Bank Pembiayaan Rakyat Syariah dalam Mengimplementasikan Keuangan Inklusif Melalui Pembiayaan UMKM. IKONOMIKA, $2(2)$,

177. https://doi.org/10.24042/febi.v2i2.1639

Rini, D. P. (2013). Review Kajian Mingguan LiSEnSi “Financial Inclusion.” Retrieved February 18, 2021, from ." Lisensi UIN Jakarta website: 
Novia Nengsih

https://lisensiuinjkt.wordpress.com/2013/12/25/review-kajianmingguan-lisensi-financial-inclusion/

Risya, H. S. (2009a). Zakat for Poverty Alleviation. Jakarta: PP LAZISNU.

Risya, H. S. (2009b). Zakat Untuk Pengentasan Kemiskinan. Jakarta: PP LAZISNU.

AL-ARBAH | 244 Rodhoni, A., \& Hamid, A. (2008). Lembaga Keuangan Syariah. Jakarta: Zikrul Hakim.

Rosyadah, P. C., Arifin, N. R., Muhtadi, R., \& Safik, M. (2020). Factors That Affect Savings In Islamic Banking. AL-ARBAH: Journal of Islamic Finance and Banking, 2(1), 33-46. https://doi.org/10.21580/alarbah.v2i1.5499

Saefuddin, A. M. (1996). Pengelolaan Zakat Ditinjau Dari Aspek Ekonomi. Bontang: Badan Dakwah Islamiyah, LNG.

Sanjaya, I. M. (2016). Financial Inclusion and Inclusive Growth: An InterProvincial Analysis in Indonesia. Buletin Ekonomi Moneter Dan Perbankan, 18(3). https://doi.org/https://doi.org/10.21098/bemp.v18i3.551

Shatibi, A. I. (n.d.). al-muwafaqad fi Usul asy-Sharia. Riyadh: Maktabah al-Riyadh al-Hadisah.

Suangkupon, A., Ismail, N., Sucipto, A. N., \& Purwengtyas, S. (2014). DIREKTORI PRODUK KREDIT DAN TABUNGAN PERBANKAN: SEKALIMANTAN TENGAH TAHUN 2014 - Akmaluddin Suangkupon, Nanang Ismail, Azhari Novy Sucipto, Setijanti Purwengtyas Google Books. Retrieved February 17, 2021, from Unit Akses Keuangan dan UMKM KPwBI Prov. Kalteng website: https://books.google.co.id/books?id=aMq9BgAAQBAJ\&printsec $=f$ rontcover\# $\mathrm{v}=$ onepage $\& \mathrm{q} \& \mathrm{f}=$ false

Suhirman. (2020). The Future Of Sharia Based Village Business Agencies Religious Response Management Of Village-Owned Enterprises In Central Lombok. AL-ARBAH: Journal of Islamic Finance and Banking, 2(1), 81-102. https://doi.org/10.21580/alarbah.v2i1.5677

Suma, M. A. (2015). Zakat, Infak, dan Sedekah: Modal dan Model Ideal 
Optimization Of Financial Inclusion Through ...

Pembangunan Ekonomi dan Keuangan Modern. Al-Iqtishad: Journal of Islamic Economics, 5(2). https://doi.org/10.15408/aiq.v5i2.2568

Suryadi, N., \& Putri, Y. R. (2018). ANALISIS PENERAPAN PEMBIAYAAN QARDHUL HASAN BERDASARKAN PSAK SYARIAH PADA BMT AL

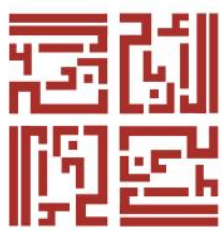
ITTIHAD RUMBAI PEKANBARU. Jurnal Tabarru': Islamic Banking and Finance, 1(1), 37-50. https://doi.org/10.25299/jtb.2018.vol1(1).2043

Sustainability Report Bank syariah X. (2019).

Sustainability Report Bank Syariah Y. (2019).

Toyyibi, A. M. (2019). Implementation Of Electronic Money In Developing Payment Transactions Through Islamic Economic Perspective. AL-ARBAH: Journal of Islamic Finance and Banking, 1(1), 19. https://doi.org/10.21580/al-arbah.v1i1.4098

Usman, S. A., \& Rasiam, R. (2019). Quotation/Parenthesis Qur'an Verse Before Beginning Deed In The Structure Of Notary Deed In Sharia Financial Institutions' Contract. AL-ARBAH: Journal of Islamic Finance and Banking, 1(1), 69. https://doi.org/10.21580/alarbah.v1i1.4168

Veithzal, R. V., \& Arifin, A. (2010). Islamic Banking; Sistem Bank Islam Bukan Hanya Solusi Menghadapi Krisis Namun Solusi dalam Mengahadapi Berbagai Persoalan Perbankan \& Ekonomi Global. Jakarta: Bumi Aksara.

Wehr, H. (1980). A Dictionary of Modern Written Arabic. Beirut: Librarie du Liban.

Yusanto, M. I. (2001). Zakat and Islamic economic education. Jakarta: Caring for the People. 